\title{
Adrift ON THE OCEAN: \\ a study of K.S. Maniam's displaced characters
}

\author{
Transforming Cultures eJournal, \\ Vol. 4 No 2 November 2009 \\ http://epress.lib.uts.edu.au/journals/TfC
}

\section{Susan Philip ${ }^{1}$}

\begin{abstract}
This paper analyses two plays by Malaysian Indian author K.S. Maniam, examining his ideas about the necessity to rearticulate state-authored, essentialising notions of cultural and ethnic identity towards the creation of a more hybrid and inclusive identity which does not demand allegiance to a single, rigidly defined culture. Maniam's main concerns in this context will be examined through a close analysis of his plays The Cord and The Sandpit: Womensis. My analysis of these two plays will be framed by the ideas articulated in Maniam's 2001 paper "The New Diaspora".

[Maniam, Malaysia, identity]
\end{abstract}

In this paper, I will analyse two plays by Malaysian Indian author K.S. Maniam, to examine his ideas about the necessity to rearticulate state-authored, essentialising notions of cultural and ethnic identity, towards the creation of a more hybrid and inclusive identity which does not demand allegiance to a single, rigidly defined culture. Where the Malaysian state demands a monocular focus on just one culture, further defined by monolithic constructions of 'race', Maniam advocates embracing multiple cultures, thus producing "an ever-widening sense of the world". ${ }^{2}$ The state-authored approach, I argue, creates a sense of diasporic nostalgia which fixates on the notion of belonging to and practicing the culture of an 'original' homeland. Maniam's approach

\footnotetext{
${ }^{1}$ Susan Philip is an Associate Professor in the English Department of the Arts Faculty, University of Malaya. Her research focuses on literary representations of culture and identity. Some of the ideas in this paper have appeared in her previous articles, (2003) "The Evolving Identity of Malaysian Indians: A Comparison of K. S. Maniam's The Cord and Allen Perera and Indi Nadarajah's Quid Pro Quo" in Chitra Sankaran, Leong Liew Geok and Rajeev Patke (eds.) Complicities: Connections and Divisions. Bern, Peter Lang: 189 - 98 and (2004) "Diasporic Spaces in K. S. Maniam's The Sandpit: Womensis", Asian Theatre Journal, 21(2): 177 - 86.

2 K. S. Maniam (2001) "The New Diaspora", University of Calgary, p.11, 10 May 2001 http:// www.ucalgary.ca/UofC.eduweb.eng1392/492a/articles.maniam-dias.html accessed 10 May 2001.
} 
to diaspora is more inclusive and embraces hybridity, moving towards the production of a new cultural identity. Maniam's main concerns in this context will be examined through a close analysis of his plays The Cord and The Sandpit: Womensis. ${ }^{3} \mathrm{My}$ analysis of these two plays will be framed by the ideas articulated in Maniam's 2001 paper "The New Diaspora".

The Cord, written and first staged in Kuala Lumpur in 1984 by the Five Arts Centre, ${ }^{4}$ details the conflicts occurring between various characters who work on a rubber plantation in Malaysia. The conflict takes place on many levels - class, family, generation, gender. The central characters struggle about issues such as belonging and social position. The social structure Maniam paints is grimly realistic, and any sense of place developed by the characters during the course of the play is fragile and tenuous at best.

First staged in 1990 in Kuala Lumpur, again by the Five Arts Centre, Sandpit shows how the two lead characters seek belonging on a more abstract level than that found in Cord. The play presents the psychic conflict between the two wives of a local gangster, as they wait for their absent husband to reappear. Despite the differences in their values, beliefs and responses they finally meet on the level of common hybrid ground.

Both plays can be seen as representing stages in Maniam's argument about 'The New Diaspora' - a hybrid, participatory kind of diaspora which partakes as fully as possible of its new home, rather than being merely lost in a backward-looking, nostalgic haze.

To what extent can we call the Malaysian Indian experience 'diasporic'? $?^{5}$ I differentiate diaspora from migration by the persistent urge of diasporic communities to constantly look back to the homeland. As suggested by Susheila Nasta, "diaspora, does not only create an unrequited desire for a lost homeland but also a 'homing desire', a desire to

\footnotetext{
${ }^{3}$ Henceforth, these plays will be referred to as Cord and Sandpit.

${ }^{4}$ A Malaysian arts collective which aims to encourage the development of local art forms.

${ }^{5}$ I would like to clarify that there are Malaysian Indians from a wide number of Indian ethnic groups. For the purposes of this paper, I use the word 'Indian' to refer not only to the Subcontinent and those of subcontinental origin, but more specifically to Malaysian Indians of Tamil extraction, and the Indian culture to which I refer is also specifically Tamil and Hindu. This is mainly because this is the context within which Maniam writes.
} 
reinvent and rewrite home as much as a desire to come to terms with an exile from it". ${ }^{6}$ Robin Cohen notes the "sense of unease or difference that diaspora peoples feel in their country of settlement [which] is paralleled by a tendency to identify instead with coethnic communities in other countries". 7 This comment indicates a desire to 'reinvent' home across national borders - perhaps at the expense of a national identity. These views of diaspora are pertinent in the Malaysian Indian case, though the diasporic identity is not necessarily created by the 'diasporic' people.

In 1931, the Census Report of Madras stated that the Indian emigrant "takes his own world with him and sets it down in his new surroundings". ${ }^{8}$ This remark suggests a reluctance on the part of the Indian emigrant to detach him or herself from India, and implies that because of the nostalgic look back at India, he or she is unable to become more grounded in the new home, thus reinforcing his or her own position as perpetual outsider. In the context of Malaysia, which has a sizeable number of citizens of Indian origin, this urge towards nostalgia and a sense of exile has different origins and implications.

Indian migration to Malaysia has a very long history, but was most active in the nineteenth century. Most of the migrants at that time were indentured labourers, but there was also some voluntary migration (traders, clerks, etc.). Voyaging from India across the Indian Ocean in the nineteenth century, migrants from the subcontinent to Malaya found themselves suspended between two 'homes', at home in neither. Encouraged by the colonisers to continue to see themselves as belonging to the subcontinent, they felt like, and were treated as, sojourners who were in Malaya on a strictly temporary basis. They were always aware of another home to which they 'belonged'. This dilemma has not disappeared with the end of colonialism. Nationalistic post-independence policies which position only the Malays (among the country's major ethnic groups) as 'native' have created an enforced diasporic nostalgia among Malaysians of migrant descent (that is, mainly Indian and Chinese Malaysians). In a nation that defines individuals in narrow and rigid terms of race and culture, it is

\footnotetext{
${ }^{6}$ Susheila Nasta (2002) Home Truths: Fictions of the South Asian Diaspora in Britain, Hampshire, Palgrave: 7 .

${ }^{7}$ Robin Cohen (1999) "Rethinking 'Babylon': Iconoclastic Conceptions of the Diasporic Experience" in Steven Vertovec \& Robin Cohen (eds.) Migration, Diasporas and Transnationalism, Cheltenham, U.K. \& Northampton, Massachussetts, U.S.A., Elgar: 256 - 57.

${ }^{8}$ Quoted in Sinnappah Arasaratnam (1970) Indians in Malaysia and Singapore, Kuala Lumpur, Oxford U.P.: 65.
} 
difficult to contend with the pull between a constantly reiterated sense of belonging to an original homeland, and a fundamental but subtly unacknowledged sense of having a place within the new homeland. The reality of life in Malaysia is increasingly hybrid in terms of ethnicity, language, cuisine, and so on - but official policy is to maintain the borders between ethnic groups by stressing diversity, difference, and separation. Thus, the displacement and uncertainty of the nineteenth-century emigrant who was here, but didn't 'belong' here, has also become a part of the postcolonial condition in postIndependence Malaysia.

In a sense, Indians in Malaysia have not been able, culturally, to complete the ocean crossing: the state demands that officially, they maintain their 'original' culture - a culture that is defined in terms that limit it to sub-continental India. This deprives them of the opportunity to produce a culture that partakes of both India and Malaysia although in real, lived terms, their culture necessarily is influenced by both. The refusal to acknowledge this multiple cultural reality can be damaging to the individual's sense of where he or she belongs. Singaporean scholar Nirmala PuruShotam, for instance, has lamented that:

The strict and enclosed meaning given to origin denies tracing place and space in terms of actual birth-place. Thus, in my terms, my birth-place, my homeland, my origins are in Singapore. The procedures by which I am racially classified, even today, trace my origins to India. It has me locked to one single place in a map designed in colonial times. In an important sense, this ensures my status as a sojourner: there is the potential uneasiness as to where home really is. ${ }^{9}$

This tension between the hybrid, settled reality and the political will to highlight nonbelonging is a particular concern of K. S. Maniam. His characters face a similar dilemma. Having crossed the ocean, they find India physically cut off for them. And in their new home (which is not quite a home), they find that Malaysians of Indian and Chinese descent are considered to be of immigrant stock, always connected to a land to which they no longer belong. In that sense, the ocean crossing is never really completed. The question to be considered is, to what extent is the individual still seeking to ground his or her self in the 'original' homeland? The connection can never really be lost - but

\footnotetext{
${ }^{9}$ Nirmala PuruShotam (1998) "Disciplining Difference: Race in Singapore" in Joel S. Kahn (ed.) Southeast Asian Identities: Culture and the Politics of Representation in Indonesia, Malaysia, Singapore and Thailand, Singapore, Institute of Southeast Asian Studies: 86.
} 
is it allowed to become a debilitating burden? How far across the ocean has he or she travelled?

In his oeuvre Maniam focuses on the struggle to belong in a cultural and political landscape which often seems inimical to that struggle. His writing, which is politically aware and informed without appearing to take an overtly political stance, counters the state's articulation of issues of belonging to reach after a postcolonial, postnational identity that rearticulates its sense of belonging by rethinking and reconfiguring cultural and ethnic identities.

\section{Maniam and the New Diaspora}

Maniam grapples with this issue in his essay "The New Diaspora". He acknowledges the existence of barriers between the various groups which make up the nation, stating that "there still remains the feeling that this side-by-side divide need not be eroded or removed. It becomes an acknowledged frontier, a necessary barrier". ${ }^{10}$ State nationalist policy positions these barriers as being 'necessary' so that 'racial' demarcations, necessary to preferential economic policies, can be clearly defined; but individual grassroots response to the barriers is less accommodating and more uncomfortable. As Maniam notes, there is "the desire in the citizen to be assimilated into a much more seamless Malaysian society". "Currently, the seams within this society are all too visible. As Maniam says of Muthu, a character in his short story "Haunting the Tiger", who seeks belonging in Malaysia but never finds it, "he has to cling to an inherited sense of culture, that is, Indian culture and, at least for him, this has tragic consequences, and he dies unfulfilled". ${ }^{12}$ It is the enforced nostalgia, this clinging to inherited cultures, which creates a sense of being a member of a diaspora - exiled and always displaced.

Maniam feels, however, that Malaysian society offers opportunities for the development of a new diaspora. The diasporic identity as mooted by the state demands that each ethnic group define itself narrowly by culture - and that culture must be from the original homeland. This policy is visible in tourist shows which seek to highlight

\footnotetext{
10 "New Diaspora" (2001:4).

11 "New Diaspora" (2001:4).

12 “New Diaspora” (2001:6).
} 
Malaysian culture by displaying the various dance forms originating from the various component cultures. Maniam takes note of the state approach to multi-culturalism:

However, this has also meant that each community remain within its cultural territory, and try not to transgress into the cultural domains of the other communities. This could be an attractive feature of the country: the colourful variety of the side-by-side existence of the different cultures. But it also makes for a 'cultural entrapment,' a reluctance to enter into the perspectives offered by other cultures. ${ }^{13}$

The new diaspora which Maniam advocates for Malaysia, however, has more in common with views of the modern diaspora as straddling two homes rather than just being exiled within one home while looking nostalgically back at another. Steven Vertovec and Robin Cohen refer to "the growth of diasporic populations anchored (socially and culturally as well as physically) neither at their places of origin nor at their places of destination". ${ }^{14}$ R. Radhakrishnan, writing of Indians in the United States, suggests that:

The older generation cannot afford to invoke India in an authoritarian mode to resolve problems in the diaspora, and the younger generation would be ill-advised to indulge in a spree of forgetfulness about 'where they have come from.' It is vital that the two generations empathize and desire to understand and appreciate patterns of experience not their own. ${ }^{15}$

Maniam's definition is more specific to the Malaysian situation, but also speaks of partaking of and straddling two cultural homes:

Unlike the traditional diaspora, the new diaspora consists of men and women dispersed among various cultural communities, and who seek another, more liberated cultural community. Exiled within their own homelands, they construct and live within a common mental and imaginative space. This common mental and imaginative space is not arbitrarily or mechanically put together; it evolves from the recognition that man has been artificially categorised into a monocultural, ethnic and political being when multiplicity is his true nature. It is this multiplicity that the new diasporic man is trying to regain. ${ }^{16}$

13 "New Diaspora" (2001:6).

14 Steven Vertovec \& Robin Cohen (1999) "Introduction", in Steven Vertovec \& Robin Cohen (eds.) Migration, Diasporas and Transnationalism, Cheltenham, U.K. \& Northampton, Massachussetts, U.S.A., Elgar: p. xiii.

${ }^{15}$ R. Radhakrishnam (2003) "Ethnicity in an Age of Diaspora", Jana Evans Braziel \& Anita Mannur (eds.) Theorizing Diaspora: A Reader, Oxford: Blackwell: 123.

16 "New Diaspora” (2001:10). 
Here, Maniam challenges the policy (which serves the nation-building policies of Malaysia) to maintain a limited number of monocultural categories, into one of which every Malaysian must fit. This policy, which emphasises native identity for some groups, and 'foreign' origins for others, constructs a diaspora which is expected to feel exiled from and nostalgic for the original homeland, and which can never feel 'at home' in the new place. They are, thus, effectively "[e]xiled within their own homelands"; to counter this sense of exile, it is necessary to be anchored in both places rather than one, to remember both where one is from and where one is - that is, to embrace multiplicity; and from this, perhaps, will arise a sense of where one is going - a sense of a multicultural future waiting to be produced.

The two plays under consideration here trace the journeys of a group of people moving towards multiplicity. Some six years separate the staging of the two plays, and analysis shows development in Maniam's ideas about diaspora and belonging. There is a teleology of belonging, as the characters in the later play move with more certainty towards a multiplicity which partakes of both India and Malaysia. In this paper, I suggest that in Cord and Sandpit, Maniam shows the beginning of a progression of thought and attitudes which indicates a growing awareness of the need to straddle the ocean separating India and Malaysia. Maniam is aware of "the dangers of the fixity and fetishism of identities within the calcification of colonial cultures", ${ }^{17}$ though it should be noted that here, the 'calcification' comes from the post-independence state. Neither should people step completely over into Malaysia and "indulge in a spree of forgetfulness". ${ }^{18}$ What is needed is something more fluid, more open to change, adaptation and negotiation. To achieve this, the nation's monocultural definitions, in which races are essentialised into three narrow categories and then linked to specific cultures from the original homeland, must be widened. One of the problems with this, however, is that hybridity (in race, culture or language) is not officially acknowledged, and the official mindset of difference and separation has to a large extent been absorbed by the populace, often despite the fact that they live hybridised lives. There is even an underlying sense that the individual's culture, preserved from the homeland, is under threat from the hybrid possibilities of Malaysian life.

\footnotetext{
${ }^{17}$ Homi Bhabha (1994) The Location of Culture, London, Routledge: 9.

${ }^{18}$ Radhakrishnan (2003: 123).
} 
For example, V. Suryanarayan, speaking of the situation among Malaysian Indians in the late twentieth century, contends that:

The younger generation is slowly getting deculturised and immediate steps should be taken to halt these dangerous trends. The only way by which a cultural renaissance can take place in Malaysia is by strengthening relations with India. ${ }^{19}$

This response is understandable; in a social structure which defines national culture as being essentially the culture of the majority ethnic group, minority groups react strongly against the potential marginalisation (or even obliteration) of their languages and cultural practices. But the phrase "cultural renaissance", and the suggestion that cultural ties with India need to be strengthened, imply that Indian culture in Malaysia needs to be re-born in the same form that it took in India, rather than to be re-formed in a Malaysian context.

Maniam challenges this view, articulating the need to look beyond narrow cultural and linguistic borders. Malaysia's "new diaspora does not seek to be reassured by an imagined cultural stability. It is prepared to adopt and extend the chameleon outlook, that is, live within an ever-widening sense of the world". ${ }^{20}$ Clearly, what is needed is neither a monocular rejection nor a wholesale re-appropriation of 'India', but a conscious melding of India and Malaysia into something new.

Radhakrishnan points obliquely to the complications involved in refusing the hybrid space and insisting instead on absolutes, when cultural identity can never actually be absolute:

Is the 'Indian' in Indian and the 'Indian' in Indian-American the same and therefore interchangeable? Which of the two is authentic, and which merely strategic or reactive? To what extent does the 'old country' function as a framework and regulate our transplanted identities within the diaspora? Should the old country be revered as a pre-given absolute, or is it all right to invent the old country itself in response to our contemporary location? Furthermore, whose interpretation of India is correct: the older generation's or that of the younger; the insider's version or the diaspora? ${ }^{21}$

\footnotetext{
${ }^{19}$ V. Suryanarayan (1982) "Indians in Malaysia: The Neglected Minority” in I. J. Bahadur Singh (ed.) Indians in Southeast Asia, New Delhi, Sterling: 47.

20 “New Diaspora” (2001:11).

${ }^{21}$ Radhakrishnan (2003: 123).
} 
What he points to - an issue which Maniam takes up in the plays studied here - is the impossibility of an 'either-or' position; within the Malaysian social framework, according to Maniam, it must be a 'both-and', liminal position.

To this end Maniam juxtaposes characters caught, uneasily, within the dilemma of whether to adapt or not. In his plays, The Cord and The Sandpit, some of his characters (Muniandy in Cord, Santha in Sandpit) show themselves to be still, to a large extent, rooted in India rather than Malaysia. While they have, physically, made the oceancrossing, culturally they remain on the other side of the water. Fearful of losing their connection to home, or uncertain if they belong to this new land, or unconvinced by their relationship with the ancestral home, his characters in The Cord and The Sandpit struggle to find some sense of place. This can only come with an acknowledgment of the various pulls and influences on the ethnically- and culturally-defined individual so that, in crossing the Indian Ocean, they consciously acknowledge that to some extent, they are no longer quite 'Indian' but that, at the same time, 'India' is an inextricable part of them. Muniandy's son, Ratnam, and Santha's rival, Sumathi, are losing that connection with the 'motherland', beginning to find the imported and reverently preserved customs and beliefs irrelevant and overly binding on their freedom. Sumathi in particular is more concerned with creating a new space within the new homeland. They must, however, also root themselves in the soil of Malaysia, thus becoming more than the crudely essentialised racial/cultural categories which the authorities impose on them. By straddling the ocean, they create within themselves a liminal space that is neither India nor Malaysia (or at least, not as these are articulated by the state). As Bhabha points out: “These 'in-between' spaces provide the terrain for elaborating strategies of selfhood - singular or communal - that initiate new signs of identity". ${ }^{22}$

In the process of narrating the psychic dilemma of his displaced characters, Maniam also consciously challenges the essentialised racialised cultural spaces within which individuals in Malaysia are enclosed; as Gabriel notes, "his works reject essentialist notions of national and ethnic identity for more processual and historically contextualized definitions from a perspective in diaspora". ${ }^{23}$ Maniam's characters

\footnotetext{
${ }^{22}$ Bhabha (1994: 1).

23 Sharmani Patricia Gabriel (2005) "Nation and Contestation in Malaysia: Diaspora and Myths of Belonging in the Narratives of K.S. Maniam”, Journal of Southeast Asian Studies 36(2): 238.
} 
grapple with state-authored impositions, not always successfully. But his narrations open up new and more congenial spaces of belonging within the nation.

\section{The Cord}

In The Cord, Maniam articulates the need to recover the lost home, while also settling in the new home, through the different generation-bound attitudes of Muniandy and Ratnam, father and son who work on a rubber estate. Muniandy came to Malaysia from India, bearing with him signifiers of the culture of the homeland - the $u d u k u$, a small drum given to him by his grandfather, meant to function as "a voice larger than [his] own to guide" him in the foreign land; ${ }^{24}$ and the thundu, a shawl worn over his shoulder. The latter serves as a symbol not only of his culture and heritage, but his dignity and authority. Malaysia-born Ratnam, however, holds on to different symbols, which are far more materialistic than the mystical, abstract symbols held dear by his father. Ratnam dreams of a Yamaha motorcycle, a machine which encompasses ideas of power, wealth and escape.

The deep gulf between the symbols prized by the two men is reflective of the huge difference in their attitudes to the past and the present. The song Ratnam sings at the beginning of the play articulates this gulf; he contrasts his father's cultural rigidity with his own ability to change:

The old man won't run from my hold, Wearing the white vesti, holding the coconut!

Not swaying like me, stiff as a pole;

Not shaking like me, proud as a priest. ${ }^{25}$

He sees his father as being mired in the past, wearing traditional clothes, and holding the coconut, which is sometimes used in Hindu prayer rituals, while he himself knows how to "confront [...] the modern times", 26 where Muniandy is rigid and "stiff" in his apparent refusal to change, Ratnam see himself as being more flexible, "swaying" and bending as needed. This deliberate contrast between the two generations recalls Radhakrishnan's comment about the dangers of either valorising or forgetting the past.

\footnotetext{
${ }^{24} \operatorname{Cord}$ (1994: 44).

${ }^{25} \operatorname{Cord}(1994: 27)$.

${ }^{26}$ Cord (1994: 28).
} 
The danger of forgetting the past is underscored by Ratnam's drunkenness and general shiftlessness as he "comes lurching down the steps" while his children are "heard crying and clamouring for food". ${ }^{27}$ Completely caught up in his materialistic vision of the new world, he neglects his family responsibilities, unlike his father, who "tried to educate" Ratnam, as a way of fulfilling his own parental responsibilities. ${ }^{28}$ Muniandy, meanwhile, is marginalised and laughed at by his neighbours, and scorned by his son, for holding on to the traditions of the past.

Yet despite these differences, both men show themselves to be connected in their dreams and desires. Ratnam wants to escape from the life on the estate, while Muniandy came to Malaysia in order to escape the narrow horizons of India. ${ }^{29}$ For both, the dream of escape has left them unanchored and drifting, because neither has managed to reconcile original home and new home, tradition and the modern. Muniandy, however, has some insight into the possibility of reconciling the two.

Muniandy is a seer, and uses the $u d u k u$ to enter into a trance state in which he can see the future. However, on the journey across the ocean, there seems to have been some loss of its mystical status, reflecting the psychic and spiritual loss experienced by the immigrants in the process of making the voyage. Muniandy calls the drum "the hourglass of the universe", a receptacle which "contains everything", but his neighbours only "laugh in ridicule". ${ }^{30}$ Functioning in India as a respected prophetic voice, in Malaysia the drum's significance is debased - Muniandy's fellow labourers want the voice of the drum to guide them to nothing more meaningful than winning lottery numbers. The thundu also has changed its function in some way. In India, it "carried dignity", but "in this country, it has turned into a rag. I use it as a whip, I use it to soak up the sweat on my body. It's a thing of many uses. I never thought about all of them when I was there"). ${ }^{31}$

Muniandy's cultural heritage, preserved from India, has been unable to survive the journey intact. Meaning loses its specificity once divorced from the originary soil. But

\footnotetext{
${ }^{27} \operatorname{Cord}(1994: 28)$.

${ }^{28} \operatorname{Cord}(1994: 29)$.

${ }^{29}$ Cord (1994: 89).

${ }^{30} \operatorname{Cord}(1994: 46)$.

${ }^{31}$ Cord (1994: 72).
} 
Muniandy does not discard these symbols. The thundu may not symbolise dignity anymore, but it has become useful and valuable in a different way in Malaysia. The $u d u k u$ also must begin to speak in a different voice. Having stopped using the drum, he now declares that he will use it again to "find my words, myself" rather than repeating his grandfather's words; he declares further that "I shall enter the past and so release myself from it". ${ }^{32}$ He cannot wholly reject the past, but must use it as a way forward.

Ratnam seems more unstable than Muniandy, despite having been born in Malaysia and, therefore, not straddling two homes and two cultures in the same way. This instability is at least partly due to his condition of enforced diasporic nostalgia, which leaves him feeling culturally displaced. Maniam presents the father, Muniandy, as the main source of the diasporic desire to look back. This reflects the position of the first-generation migrants who did not see themselves as migrants but as sojourners, still primally attached to the original homeland and its culture. But Ratnam, it becomes clear, feels no such attachment. India is foreign to him, as can be seen from his responses to the cultural demands and values of his father's homeland.

Maniam makes Muniandy's deceased wife, Lakshmi, function as the repository of culture, a role frequently assigned to women. Cultural purity is seen as something to be preserved, and in this highly gendered view of culture, woman is the sacred female body which physically embodies the purity of culture. In this context, it is significant that Lakshmi dies soon after giving birth to Ratnam - he therefore does not know her at all. Symbolically, he has no knowledge of and feels no connection with his 'mother' culture:

Muniandy: You don't respect your mother.

Ratnam: I never saw her.

Muniandy: (wearily) There are so many pictures in the house.

Ratnam: Too many! Life and blood! I'm interested in life and blood. ${ }^{33}$

The culture to which Muniandy adheres, represented by Lakshmi, is, to Ratnam, nothing more than a picture of a dead person, seemingly unconnected to his life.

\footnotetext{
${ }^{32} \operatorname{Cord}(1994: 46)$.

${ }^{33} \operatorname{Cord}$ (1994: 31).
} 
Ratnam replaces Muniandy's devotion to his culture with dreams of material gain dreams which, given his habits of laziness and drunkenness, are unlikely to come to fruition. He has, therefore, been unable to replace the idea of culture with anything else worthwhile. In this context, Maniam's positioning of Ratnam as an estate labourer is significant. He is meant to work the land, but Ratnam and his fellow labourers are mere workers, with no deeper spiritual or even financial investment in the success of the estate. The estate structure, then, is inimical to the idea of belonging; the estate can never belong to Ratnam, so he cannot belong to it. Viewed symbolically, this idea also links back to the notion of enforced diaspora: individuals of migrant descent cannot belong to or own the land/nation in the same way as the natives do. Ratnam, then, is deeply displaced: culturally he is not anchored in the 'original' culture. But he is also unable to find cultural anchorage in a nation which insists on essentialised, backwardlooking ideas of culture, and does not allow him the space to produce a new, hybrid culture.

Maniam also suggests that 'preserving' one's culture is not actually possible. Again, the gendered view of culture as being enshrined within the female body is deployed, and the fate of Lakshmi comes to reflect the position of the original culture within the new homeland. Transplanted to foreign soil, Lakshmi is vulnerable. Always alone because her husband is at work, she is cut off from the traditional social and familial networks which would have supported and sustained her in India. Her constant refrain is "alone, alone", and her vulnerability is underscored by the hovering presence of predatory men. ${ }^{34}$ The purity of the culture of the homeland, then, is fragile, under constant threat. She is raped by Muthiah, Muniandy's superior. Ratnam is conceived as a result of this rape, and Lakshmi dies soon after his birth, destroyed by violence and brutality.

Symbolically, this incident shows that removal from the homeland will result in some destruction or violation of the original culture. But Maniam does not focus solely on violation. The tale is not narrated directly; rather, Muniandy plays his $u d u k u$ and summons the spirit of his dead wife through another person's body. This serves to distance us somewhat from the tragedy of the event. But apart from this, Maniam's focus is on the fact that Ratnam is the direct result of this rape. He is the product of this violation of a culture by the conditions within a new homeland - he has the potential to embody a new and hybrid culture.

${ }^{34} \operatorname{Cord}(1994:$ 49). 
Maniam does touch on a possible solution to the displacement felt by both Muniandy and Ratnam, with the $u d u k u$, symbolic of the voice of India, potentially functioning as a kind of two-way bridge across the ocean. As he plays the drum, Muniandy becomes aware that he has so far been speaking in his grandfather's voice; he realises that he needs to "find my words, myself". ${ }^{35}$ But it is clear that, since he still uses the $u d u k u$, his voice and words will be informed by India. This link with India is also embodied in the symbol of the cord - Muniandy's shawl (thundu), which can be read as the umbilical cord tying Muniandy to his motherland. In the process of leaving the womb of the motherland, the cord has been stretched and twisted, although not cut. It is necessary to take on board these changes, the stretching and twisting, without actually cutting the cord.

Many Malaysian Indians do feel the need to actually make a concerted effort to maintain these cultural links with India, in the face of attrition caused by incessant exposure to other cultures and languages, combined with constant marginalisation of their own culture. Arasaratnam, like Suryanarayan, fears the dilution of the Indian cultural heritage among Malaysian Indians (specifically, among those not educated in Tamil): "They are growing up, particularly those at school, as a rootless generation. In a country still divided into its distinct cultural traditions, a group that alienates itself from what is its own will have no cultural home". ${ }^{36}$ However, the insistence on maintaining "distinct cultural traditions" will result in alienation from each other, and there will then be no culture which speaks of the new home, only a culture which is "preserved" (in the sense of being dead and pickled $)^{37}$ and unchanging, an increasingly irrelevant holdover from the original homeland.

Muniandy becomes aware of this to some extent, hence his declaration that he needs to find his own words, although mediated through the voice of his grandfather's drum. Ratnam, too, gropes his way towards a new awareness of his position straddling the

${ }^{35} \operatorname{Cord}(1994: 46)$.

${ }^{36}$ Arasaratnam (1970: 195).

${ }^{37}$ I take this idea from Kwok Kian-Woon, who notes that "the notion of 'preservation' [implies] that what is preserved is something already quite dead and that what we try to do is to keep it from decaying or decomposing further", Kwok Kian-Woon (1993) "The Problem of 'Tradition' in Contemporary Singapore", in Arun Mahizhnan (ed.) Heritage and Contemporary Values, Singapore, Times Academic: 17. 
ocean, starting to allow his body to function as the in-between space where a hybrid culture can emerge. Ratnam was actually fathered by Muthiah, an estate administrator who has also rejected Indian culture: he first appears wearing shorts, rather than the usual vesti (sarong); he also speaks English in "false English tones" and has tried to teach Ratnam English. ${ }^{38}$ This could form part of Ratnam's cultural heritage, but he is not comfortable with it, and it will leave him equally displaced. Finally, when he is told that Muthiah, rather than Muniandy, is his father, he recognises that Muthiah and his ways are alien to him. He chooses instead to turn to Muniandy and deliberately call him "Father". Muniandy finalises the severing of the connection between Ratnam and Muthiah by declaring, "You've a life ahead. He never gave it to you. That's my gift to you". Ratnam responds "I understand your language, Father". ${ }^{39}$ Here, Ratnam rejects Muthiah's attempts to teach him English; instead, he declares a kind of linguistic (and thus cultural) kinship with Muniandy. Maniam is pointing here to a conscious choice to meld the culture of India (embodied by Muniandy) with the realities of life in Malaysia.

In this play, Maniam asks: "How long can the cultural values and traditions of a race survive outside its natural environment, against foreign elements in a new land?" Through the figure of Ratnam, he answers that they cannot survive as they are for very long. But he also suggests that it is important that, rather than merely surviving, they should change and adapt - an idea explored more fully in Sandpit.

\section{The Sandpit: Womensis}

In Sandpit, Maniam's characters move further along the road to finding the "common mental and imaginative space", 41 as Maniam puts it, which will allow them to claim a 'multiple' rather than a monocultural identity, partaking of both their traditional heritage, and the new homeland in which they live. The play moves towards a vision of a larger, more harmonious hybridity, in which those of migrant descent accept a multiplicity of influences: according to Maniam, the migrant should be "not only aware of his own culture but also of the cultures around him, and of those inherited through his

\footnotetext{
${ }^{38} \operatorname{Cord}(1994:$ 64).

${ }^{39} \operatorname{Cord}$ (1994: 92).

${ }^{40}$ Joyce Moy (1994) "Discord in Estate of Man”, in K. S. Maniam (ed.) Sensuous Horizons: The Stories and the Plays, Kuala Lumpur, Skoob: 95.

41 “New Diaspora” (2001: 10).
} 
education and reading. He therefore occupies several cultural spaces just as he does several imaginative spaces". ${ }^{4}$ Further, Maniam sees "the new diasporic man" in the Malaysian context as actively rejecting the artificial categorisation of individuals into "monocultural, ethnic and political [beings] when multiplicity is [their] true nature". 43 In The Cord, Muniandy vaguely apprehends this point, while Ratnam decides to embrace multiplicity by claiming kinship with India as well as Malaysia. In The Sandpit, the two protagonists, Santha and Sumathi, explore the separate cultural spaces which they have to this point been inhabiting, and finally come to a remarkable point of fusion which is liberating and empowering.

Where The Cord uses the drum and the shawl to symbolise the connection with India and the original culture, The Sandpit puts greater emphasis on the mental and spiritual aspects of the connection by focusing it through the relationship of the two women to their husband, Dass, and to each other. The characters in Sandpit are further removed from India those those in Cord. Muniandy has come to Malaysia directly from India. In Sandpit, both Santha and Sumathi are, like Ratnam, second-generation migrants with no direct experience of India and its culture. Also, in the play, we do not see their parents, who might have that direct experience. Thus they seem quite far removed, in some ways, from the subcontinent, and they are therefore more free to discard, adapt or adopt its culture. Potential owners of a fluid, hybrid new culture, they must make a conscious and deliberate effort to produce a culture together by moving outside the allowable boundaries of cultural identity as articulated by the state. Even though she does not have a direct link to India the way Ratnam does (though Ratnam initially rejects this link), Santha finds herself still very much controlled by 'Indian' values, practicing culture the way she believes it has been traditionally practiced. Sumathi (again like Ratnam) rejects a set of traditions she finds stifling. Eventually, the women realise that neither of them can exist in isolation from the other, practicing their cultures separately.

Santha, bound by tradition, is respectful of Dass and mindful of her 'place'. Even though Dass is not in the house, Santha maintains her 'place', sitting on the floor by his chair. He can be read as symbolising the traditional, patriarchally dominated culture of India, even though he too is a second-generation migrant. Santha, for him, is the proper,

\footnotetext{
42 "New Diaspora" (2001: 10).

43 "New Diaspora" (2001: 10).
} 
traditional Tamil Hindu wife; like Lakshmi, she maintains the purity of her culture within her body. Her confinement within the borders of this culture is represented by her garb - she wears a sari, tied tightly, with a "wide and stiff" border. ${ }^{44}$ Interestingly, however, she does not follow these traditions blindly. Where Muniandy's wife Lakshmi, also a follower of tradition, appears fragile and vulnerable, Santha is more self-assured and tough-minded. She appears to have inner resources of her own so that, although she is as alone as Lakshmi, she is neither vulnerable nor forlorn. Where Lakshmi is threatened by the presence of other men around her, Santha is able to come into contact with Dass's gangster friends without being harmed; knowing them for what they are, she does not allow them to threaten her. This suggests that she already embodies a level of hybridity. She cannot maintain a 'pure' culture because she is already, inevitably, hybrid, and this hybridity allows her to slowly articulate some scepticism about the purity of tradition.

Santha represents the questioning insider who, by questioning, can bring about collapse or change:
Santha may be shaped and guided by tradition, but she is also the insider in that tradition questioning its vitality and contemporaneity. Thus, it can be seen it is a case of tradition examining itself for its continued validity and where weaknesses are discovered, these flaws are removed or kept to the minimum. ${ }^{45}$

This, then, is not the 'preserved' tradition which is used to categorise most Malaysians. Rather, it is a vital, growing tradition which adapts to its environment and to current needs. Thus, it eventually empowers Santha. In this, Santha is significantly different from Lakshmi; as the bearer of culture, Lakshmi preserves the traditions within her body. When that body is violated by rape, she has nothing else to sustain her, and is therefore destroyed. For Santha, however, traditions which do not sustain her are to be questioned, challenged, and perhaps removed.

In her marriage to Dass, for example, she declares that "everything was done correctly", all the ceremonies carried out properly. ${ }^{46}$ The end result, however, is that "Now there's

\footnotetext{
${ }^{44}$ Sandpit (1994: 183).

${ }^{45}$ K. S. Maniam (1994) "Preface" in K. S. Maniam (ed.) Sensuous Horizons: The Stories and the Plays, Kuala Lumpur, Skoob: xiv.

${ }^{46}$ Sandpit (1994: 185).
} 
nothing to show for the marriage". ${ }^{47}$ Rather than collapsing beneath the weight of the revelation that preserved tradition alone cannot sustain her, Santha examines their life together in a tough, clear-minded way. Ultimately, she rejects the centrality of Dass to her life. For most of the play, she treats his chair as if he were still in it. Towards the end, however, she sits in it with no sign of fear or trepidation. She is able to break the hold it has on her.

Interestingly, however, she sits in the chair only to show that she is not like Sumathi, Dass's second wife. When Santha sits in the chair, it is to scornfully imitate Sumathi's lax, slutty behaviour; she imitates it, finds it wanting, and rejects it. Sumathi violates all the borders put in place by culture and tradition. Unlike the primly tied and tucked Santha, Sumathi wears a tight (revealing) T-shirt and a loose, flowing skirt; her movements also have an ease and expansiveness not visible in Santha. She is unhampered by Santha's adherence to tradition, and does not treat Dass's chair with reverence.

Sumathi is the brash interloper into Santha's ordered, bounded life. It is implied that Dass has rescued her from a life of prostitution. We are told that she was punished by her family for exhibiting a too-open physicality and sensuality, and as a result ran away from their stifling propriety and rigid adherence to rules of conduct and morality. Santha disapproves of the very tactile, physical nature of the relationship between Sumathi and Dass. Nothing about their relationship and marriage was "done correctly". And yet, both women find themselves in precisely the same situation - betrayed, somehow, by the traditions that govern their lives, waiting for the return of their missing husband. It is interesting that Dass does not seem to expect Sumathi to behave in the same way as Santha. With Sumathi he is more open, more lax about tradition, more physical and sensual. It is as if he recognises the need for both Santha's embracing of tradition and Sumathi's rejection of it. But with Dass, the two extremes of tradition, represented by Santha and Sumathi, continue to inhabit separate and isolated bodies. Dominated by the patriarchal will, they remain separated - just as racial and cultural categories in the Malaysian state's view remain separate. But now that Dass has disappeared, the two women begin to find common ground. Different as they are, they share a deep and vital connection.

\footnotetext{
${ }^{47}$ Sandpit (1994: 185).
} 
Although Maniam appears to embody two opposing viewpoints within the bodies of Sumathi and Santha, it is not a simple case of presenting them as binary opposites, of pitting tradition against modernity. Neither tradition nor modernity, in opposition, is going to work. Santha's adherence to tradition "insists on correctness and consideration" but also "keeps a person at a distance from another" 48 - it is, then, incomplete; it is found wanting in some way.

Maniam suggests that Sumathi, the younger wife, has an "emergent" tradition", one which thrives on closeness and freedom, rather than distance and propriety; unlike Santha, Sumathi seems less restricted. For example, she is free to leave the confines of the house. She contrasts herself with the confined and sheltered Santha, who is beaten down when in public because: "She didn't know the people on the streets. Only her neighbours. We must know the words on the streets". ${ }^{50}$ What this implies is a necessity to understand one's society at a fundamental, grassroots level, to become a part of that wider world, as Sumathi does. Yet her freedom, ironically, places its own boundaries around her. Sumathi, unlike Santha, is not content to sit and wait for Dass to return. She decides to go out and actively search for him; she therefore ends up waiting in a hotel room in a red-light district, sending out for word of him. She remains confined within this room because her relative freedom also means that she is less protected than Santha. Santha's traditional bearing removes her from the public arena. Sumathi, because she puts herself in that public arena, is in danger from predators. If she were to come out of the hotel room, or to lose the protection of Dass's name, she would be preyed upon by the local pimps. Thus, while she values "companionship, caring, playfulness [and...] a sane enjoyment of sensual life" ${ }^{, 51}$, unlike the more aloof Santha, it can be said that her emergent tradition has also been found wanting in some way.

Just as with Muniandy and Ratnam, we become aware that neither can function effectively in isolation; to try to do so is to invite failure and loss. Santha hints at the possibility of working together, when she declares that: "We'll always be together. I'll

\footnotetext{
${ }^{48}$ Maniam (1994: xiv).

${ }^{49}$ Maniam (1994: xv).

${ }^{50}$ Sandpit (1994: 206)

${ }^{51}$ Maniam (1994: xv).
} 
be the silence, you be the noise". ${ }^{52}$ Although she refers here to Dass, her remark would be more relevant to the relationship between herself and Sumathi: they balance each other, with their silence and noise, confinement and freedom, respect for tradition and rejection of it. In Sandpit, Maniam shows the two women coming together at the end, each tempering the tendencies of the other, so that a new, hybrid tradition emerges from their contact. Sumathi, the vital and physical young woman, sings and dances, rejecting "authority", "uncertainty" and "the unholy"; 53 in other words, she rejects any external attempt to control her. At the same time, however, her rejection of "the unholy" implies a strong moral centre to her 'looser', less rigid lifestyle. Santha, meanwhile, has up to this point been physically restrained and contained, reflecting her aloofness. Now, however, she begins to dance "in her own controlled and yet in a vital fashion". ${ }^{54}$ Her restraint, then, is tempered by an apprehension of energy and joy. Each woman takes on aspects of the other, because each has examined her monocular view of tradition, and found it wanting. Santha's espousal of tradition is shown to be fundamentally meaningless, while Sumathi's utter rejection of it leaves her vulnerable and unprotected. It is only in a melding of both that the women find themselves empowered and liberated from the influence of Dass, emerging into a new, shared space of existence.

Malaysian director Krishen Jit, who directed both The Cord and The Sandpit, felt that a sense of connection is deeply necessary. Talking about The Sandpit, he declares that "life together is livable but life apart is not". 55 This statement is true on many levels: Maniam has demonstrated that together, Santha and Sumathi are stronger. But the idea of 'together' can also refer, in a more metaphorical way, to the mixing of the old and new traditions, original and new homelands. Life cannot be lived unless these elements come together meaningfully. The emigrant must cross the ocean, but in crossing it, must learn to bring something of the original homeland with him or her, and to meld it spiritually with the new homeland.

\footnotetext{
52 Sandpit (1994: 212).

${ }^{53}$ Sandpit (1994: 216).

${ }^{54}$ Sandpit (1994: 216).

${ }^{55}$ Carmen Nge (1994) "Play that Challenges Director and Actors", in K. S. Maniam (ed.) Sensuous Horizons: The Stories and the Plays, Kuala Lumpur, Skoob: 218.
} 
Maniam declares that, in writing these plays, "[i]t is not clarity that moved me to enter the various personalities, $[\ldots]$ but something more unpinnable, something that has to do with understanding men and women, something that has to do with releasing those aspects of ourselves that we tuck away...". ${ }^{56}$ What Maniam is reaching after is a cultural identity that cannot be pinned down and categorised, suffocated and 'preserved', as is demanded in Malaysia now. Rather, there must be an imaginative leap which allows for the production of complex, flexible and multiple identities - "abundant images of ourselves", not the singular images produced by the state's monocular vision. Although those of migrant descent in Malaysia are constrained to always look back to the original homeland, Maniam advocates creating a new kind of diasporic vision which embraces both 'there' and 'here', 'then' and 'now', to emerge as a welcoming, hybrid space of being that allows for multiple cultural identities.

\section{Bibliography}

Arasaratnam, Sinnappah (1970) Indians in Malaysia and Singapore, Kuala Lumpur: Oxford U.P.

Bhabha, Homi (1994) The Location of Culture, London: Routledge.

Cohen, Robin (1999) “Rethinking 'Babylon': Iconoclastic Conceptions of the Diasporic Experience", in Steven Vertovec \& Robin Cohen (eds.) Migration, Diasporas and Transnationalism, Cheltenham, U.K. and Northampton, Massachussetts, U.S.A.: Elgar, $252-265$.

Gabriel, Sharmani Patricia (2005) "Nation and Contestation in Malaysia: Diaspora and Myths of Belonging in the Narratives of K.S. Maniam," Journal of Southeast Asian Studies 36: 2 (2005), 235 - 248.

Kwok, Kian-Woon (1993) “The Problem of 'Tradition' in Contemporary Singapore”, in Arun Mahizhnan (ed.) Heritage and Contemporary Values, Singapore: Times Academic, $1-24$.

Maniam, K. S (1994) The Cord in K. S. Maniam Sensuous Horizons: The Stories and the Plays, Kuala Lumpur: Skoob, 25 - 94.

— (1994) The Sandpit: Womensis in K. S. Maniam (ed.) Sensuous Horizons: The Stories and the Plays. Kuala Lumpur: Skoob, 183 - 216.

_ (1994) "Preface" in K. S. Maniam (ed.) Sensuous Horizons: The Stories and the Plays, Kuala Lumpur: Skoob, ix - xv.

_ (2001) "The New Diaspora” University of Calgary, 11 pp. 10 May 2001 http:// www.ucalgary.ca/UofC.eduweb.eng1392/492a/articles.maniam-dias.html.

Moy, Joyce (1994) "Discord in Estate of Man" in K. S. Maniam (ed.) Sensuous Horizons: The Stories and the Plays, Kuala Lumpur: Skoob, 95 - 98.

\footnotetext{
${ }^{56}$ Maniam (1994: xv).
} 
Nasta, Susheila (2002) Home Truths: Fictions of the South Asian Diaspora in Britain, Hampshire: Palgrave.

Nge, Carmen (1994) "Play that Challenges Director and Actors" in K. S. Maniam (ed.) Sensuous Horizons: The Stories and the Plays, Kuala Lumpur: Skoob, 217 220.

PuruShotam, Nirmala (1998) "Disciplining Difference: Race in Singapore" in Joel S. Kahn (ed.) Southeast Asian Identities: Culture and the Politics of Representation in Indonesia, Malaysia, Singapore and Thailand, Singapore: Institute of Southeast Asian Studies, 51 - 94.

Radhakrishnam, R. (2003) "Ethnicity in an Age of Diaspora", in Jana Evans Braziel \& Anita Mannur (eds.) Theorizing Diaspora: A Reader, Oxford: Blackwell, 119 131.

Suryanarayan, V. (1982)“Indians in Malaysia: The Neglected Minority" in I. J. Bahadur Singh (ed.) Indians in Southeast Asia, New Delhi: Sterling, 34 - 51.

Vertovec, Steven \& Cohen, Robin (1999) "Introduction" in Steven Vertovec \& Robin Cohen (eds.) Migration, Diasporas and Transnationalism, Cheltenham, U.K. \& Northampton, Massachussetts, U.S.A.: Elgar, xiii - xxviii. 